УДК 81.255

DOI https://doi.org/10.26661/2414-9594-2020-2-4

\title{
ТАКТИКИ ПЕРЕКЛАДУ МІФОНІМІВ 3 АНГЛІЙСЬКОЇ МОВИ УКРАЇНСЬКОЮ В КІНЕМАТОГРАФІ (НА МАТЕРІАЛІ ПЕРЕКЛАДУ СЕРІАЛУ «ГРА ПРЕСТОЛІВ»)
}

\author{
Великорода Ю. М. \\ кандидат філологічних наук, \\ доиент кафедри англійської філології \\ Прикарпатський національний університет імені Василя Стефаника \\ вул. Шевченка, 57, Івано-Франківськ, Украӥна \\ orcid.org/0000-0002-4913-4291 \\ yuriy.velykoroda@pnu.edu.ua \\ Кернична Л. I. \\ студентка магістратури \\ Прикарпатський національний університет імені Василя Стефаника \\ вул. Шевченка, 57, Івано-Франківськ, Украӥна \\ orcid.org/0000-0002-5950-8349 \\ liliakernychna@ukr.net
}

Ключові слова: міфонім, міфологічна картина світу, дослівний переклад, запозичення, еквіваленція.
Стаття присвячена визначенню тактик перекладу міфонімів з англійської мови на українську на матеріалі перекладу фентезійного телесеріалу «Гра престолів». На основі класифікацій міфонімів Н. Подольської визначаються основні типи міфонімів як засобів вербалізації авторської міфологічної картини світу у досліджуваному матеріалі, до яких додаються ще чотири групи, ідентифіковані у матеріалі дослідження. Основними трьома типами міфонімів у проаналізованому матеріалі стали міфотопоніми, міфоантропоніми та міфоетноніми. Проведено аналіз тактик перекладу, визначених Ж.-П. Віне і Ж. Дарбельне за кожним типом міфонімів. На основі аналізу застосування тактик перекладу визначаються три основні тактики - дослівний переклад, запозичення та еквіваленція, застосування інших тактик спостерігалося у десяти відсотках випадків. На основі кількісних підрахунків визначених тактик перекладу робляться висновки про тенденції до відтворення авторських міфонімів у серіалі «Гра престолів» 3 англійської мови на українську. Зокрема, визначено, що основною тактикою став дослівний переклад, який застосовувався під час перекладу кожного типу міфонімів. Тактика запозичення застосовувалася лише у трьох з десяти типів міфонімів, проте в абсолютних показниках виявилася дещо більш частотною, аніж тактика еквіваленції, до якої перекладачі вдавалися під час перекладу восьми 3 десяти типів міфонімів. Результати проведеного дослідження свідчать, що в переважній більшості випадків перекладу авторських міфонімів (близько вісімдесят відсотків) перекладачі послуговуються лексичними ресурсами цільової мови, а у двадцяти відсотках вдаються до тактики запозичення для збереження екзотичного характеру авторської картини світу. Суттєве домінування тактики дослівного перекладу (понад п’ятдесят відсотків) свідчить про намагання перекладачів зберегти у цільовій мові лексичне значення міфоніма, який часто є важливим для контексту оригіналу, виступає промовистою назвою та виконує функцію характеризації елементів авторської міфологічної картини світу. 


\title{
METHODS OF TRANSLATING MYTHONYMS FROM ENGLISH INTO UKRAINIAN (ON THE BASIS OF THE TRANSLATION OF THE SERIES "GAME OF THRONES")
}

\author{
Velykoroda Yu. M. \\ Ph.D., \\ Associate Professor at the Department of English Philology \\ Vasyl Stefanyk Precarpathian National University \\ Shevchenka str., 57, Ivano-Frankivsk, Ukraine \\ orcid.org/0000-0002-4913-4291 \\ yuriy.velykoroda@pnu.edu.ua
}

Kernychna L. I.

Master's Student

Vasyl Stefanyk Precarpathian National University

Shevchenka str., 57, Ivano-Frankivsk, Ukraine

orcid.org/0000-0002-5950-8349

liliakernychna@ukr.net

Key words: mythonym, mythological worldview, literal translation, borrowing, equivalence.
The article is an investigation of translation solutions applied during the translation of mythonyms from English into Ukrainian on the basis of the translation of "Game of Thrones" fantasy television series. On the basis of N. Podolskaya's classification of mythonyms, we have defined the main types of mythonyms as means of verbalization of the author's mythological worldview in the material under investigation. The classification has been complemented with four new groups identified in the film. The three main types of mythonyms in the analyzed material are mythotoponyms, mythoanthroponyms and mythoethnonyms. For the analysis of translation solutions, we applied the classification by J.-P. Vinay and J. Darbelnet for each type of mythonyms. On the basis of our analysis, we have identified three main translation solutions - literal translation, borrowing and equivalence. The other solutions have been used in fewer than ten percent of cases. On the basis of quantitative research of translation solutions, we draw conclusions about the trends in translating mythonyms in the television series "Game of Thrones" from English into Ukrainian. Thus, we have determined that the main solution was literal translation, which was used in the translation of each type of mythonyms. Borrowing was applied in only three of ten types of mythonyms, yet in absolute figures this solution was used more frequently than equivalence, which was applied during the translation of eight types of mythonyms. The results of the research reveal that in most cases (about eighty percent) when translating mythonyms, translators prefer to use lexical resources of the target language, while in twenty percent of cases they borrow the source lexeme to preserve the exotic nature of the author's mythological worldview. The dominant use of literal translation (more than half of all cases) is evidence of the translators' efforts to preserve the lexical meaning of the mythonym in the target language, as this mythonym is often significant for the context of the original, serves as an expressive name and functions for the characterization of the elements in the author's mythological worldview. 
Тактики перекладу лексичних новотворів, оказіоналізмів та авторських неологізмів становлять неабияку проблему як для перекладознавців, так і для перекладачів-практиків. Водночас, зі зростанням популярності фентезійного жанру в літературі та у кінематографі, а також очікуваннями доступності нових творів різними мовами майже одночасно із виходом оригіналів, ця проблема набуває особливої актуальності у наш час. Перекладу лексичних новотворів присвячено ряд праць українських перекладознавців [2; 6; 8; 9]. Фентезійні жанри, які містять свою оригінальну авторську міфологію, компонентами якої часто стають оказіональні одиниці, які не мали усталених варіантів номінації навіть в мові оригіналу (наприклад, творчість Дж. Толкіна, Дж. Роулінг тощо)? набувають все більшої популярності в останні десятиліття. Найбільш успішним у кінематографі у другому десятилітті XXI століття став телесеріал «Гра престолів», знятий за мотивами книги Дж. Мартіна «Пісня льоду й полум'я». У серіалі присутня оригінальна міфологічна картина світу, ретельно розроблена автором, яка виступає основою для сюжетної лінії та в якій часто можна знайти мотивацію поведінки та вчинків головних героїв. Разом із тим у сучасному українському перекладознавстві утворилася певна лакуна в дослідженні перекладу цього фільму, а єдина наявна наукова розвідка у цьому напрямі датується ще 2014 роком і присвячена перекладу власних назв у першій частині серії романів Дж. Мартіна [1].

Метою статті $\epsilon$ визначення тактик перекладу міфонімів 3 англійської мови на українську у серіалі «Гра престолів». Досягнення поставленої мети передбачає розв'язання таких завдань: 1) визначити міфоніми, які виступали засобами вербалізації авторської міфологічної картини світу; 2) типологізувати відібрані міфоніми; 3) визначити тактики перекладу для кожного типу міфонімів.

«Міфологічна картина світу - це цілісна система вірувань та уявлень первісної людини про будову навколишнього світу (реального та потойбічного), що грунтується на традиціях і міфах. У цій картині природу сприймають через богів, духів, магічні, фантастичні властивості та явища» [4, с. 77]. Міфологічна картина світу, яка є особливим типом картини світу, з одного боку, являє собою спробу пізнати і впорядкувати навколишній світ первісною людиною, а з іншого, вона виступає як своєрідне універсальне бачення сучасного світу [5, с. 270]. Міфи втратили свою визначальну роль у пізнанні людиною навколишньої дійсності через те, що наука швидко розвивається. Проте до цього часу міфи зберігаються як частина літературної спадщини, яка несе естетичну цінність i має високий ступінь прецедентності у творах різних авторів.
Багато письменників, таких як Дж. Толкін, Дж. Роулінг, Р. Говард, Ф. Лавкрафт, Дж. Мартін, створювали свої твори, грунтуючись на міфах. I. Вінтерле стверджує, що «сьогодні світ фентезійного твору», або «вторинний світ» - найважливіша категорія літератури фентезі, яка багато в чому визначає художні достоїнства, якість і популярність фентезійних творів. Практично будьякий вторинний світ будується на основі міфу, оскільки саме міф допомагає сконструювати внутрішньо переконливий, логічний i достовірний Всесвіт [3, с. 38].

Найголовніший, основоположний елемент фентезійної літератури - поєднання абсолютної вигадки і дійсності. Автори фентезі у створений собою магічний світ переносять міфологічні символи, включають міфологічних істот або створюють нових персонажів на основі міфологічних, уявні об'єкти, магічну зброю або засоби для використання магії. Звідси випливає поняття «авторської міфологічної картини світу» [7]. Міфи - важлива частина структури всесвіту, де відбувається дія серіалу «Гра престолів». Перед глядачами відкривається абсолютно новий, інший світ, який не існує в реальності, світ, який населяють вигадані народи 3 власною культурою, традиціями та уявленнями.

Свідченням авторської міфологічної картини світу «Гри престолів» виступають наявні в серіалі міфічні та міфоподібні істоти та тварини, які заселяють створений автором всесвіт, несумісний 3 нашою реальністю; вигадані народи, які вірять в різних богів та мають своє уявлення про світ; представники потойбічного світу; використання магії, наявність різних релігій, вигаданих мов. Дж. Мартін створив власні міфоподібні образи та символи, окрім того, він запозичив мотиви iз наявних міфологій (скандинавської, кельтської, грецької та перської). Водночас події в серіалі нагадують Середньовічну Європу, що помітно завдяки зображенню лицарських турнірів, колісниць, замків, у яких живуть герої серіалу.

Засобами вербалізації міфологічної картини світу $є$ міфоніми (або міфолексеми) - лексичні одиниці, що позначають міфічні істоти, об'єкти тощо. Згідно 3 А. Суперанською, міфонім - це «іменування людей, тварин, рослин, народів, географічних і космографічних об'єктів, різних предметів тощо, які в дійсності ніколи не існували» $[11$, с. 180$]$. У нашому дослідженні ми розподілили міфоніми за класифікацією Н. Подольської, в яку включені такі типи:

міфоантропонім - ім'я власне людської істоти в билинах і міфах;

міфотопонім - власна назва будь-якого географічного об'єкта;

міфозоонім - назва тварини; 
міфофітонім - назва рослини;

міфоетнонім - назви народів;

міфотеонім - назва божества в будь-якому пантеоні [10];

Оскільки до міфологічної картини світу ми віднесли ще такі мовні одиниці, для яких не було визначено окремих категорій у класифікації Н. Подольської, ми вирішили додати такі поняття: міфохрононіми - назви періодів часу, подій, свят;

міфохрематоніми - назви різних предметів: знарядь праці, зброї, інструментів, приладів, побутових предметів, коштовностей тощо. Обидва терміни утворені від термінів на позначення розрядів онімів хрононіми та хрематоніми [10, с. 161, 162].

До цієї класифікації слід додати ще дві групи, яких немає у традиційних класифікаціях міфонімів, які, однак, наявні в досліджуваному матеріалі:

міфотоксиконіми (від гр. $\mu$ $\theta$ о - міф, гр. $\tau о \xi \iota \kappa o \varsigma$ - отрута та $\lambda о \gamma o \varsigma$ - наука) - міфоніми на позначення отрути;

міфогексоніми (від гр. $\mu$ $\theta$ о - міф, герм.

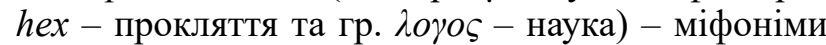
на позначення видів магії та тих, хто її практикує. У словотворі цього оніма ми застосували слово германського походження, яке, на нашу думку, краще узгоджується 3 принципами милозвучності української мови при творення нової одиниці, аніж грецький аналог магія.

Серія фільмів «Гра престолів» представляє великий інтерес із точки зору аналізу тактик перекладу. П. Ньюмарк визначає тактики перекладу як «процедури, які використовуються для перекладу тексту мовою оригіналу в текст мовою перекладу». Він стверджує, що стратегії перекладу використовуються для цілих текстів, а тактики перекладу для речень та менших одиниць мови $[12$, с. 81$]$.

Для нашого дослідження ми обрали класифікацію тактик за Ж.-П. Віне і Ж. Дарбельне, які виділяють: запозичення (borrowing) (слово 3 оригінального тексту безпосередньо переходить в цільовий), дослівний переклад (literal translation) (переклад лексичної одиниці оригіналу шляхом заміни іiі складових частин - морфем або слів їх лексичними відповідниками), транспозицію (transposition) (заміна слова однієї частини мови на іншу без зміни значення всього повідомлення), модуляцію (modulation) (зміна слова або словосполучення мови оригіналу одиницею мови перекладу, значення якої виводиться логічно), еквіваленцію (equivalence) (використання у тексті перекладу слова або словосполучення, яке в мові перекладу визнається усталеним еквівалентом) та адаптацію (adaptation) (передача ситуації оригіналу, якої не існує в мові перекладу за допомогою іншої ситуації, яку можна вважати еквівалентною) $[13$, с. 31$]$.

Отже, у ході нашого дослідження методом суцільної вибірки ми ідентифікували в оригіналі кінофільму 203 міфоніми, які виступили засобами вербалізації авторської картини світу. На такому етапі ми класифікували ці міфоніми за їх типами, описаними вище. Кількісні результати вибірки показано у таблиці 1.

Таблиця 1

Типологія міфонімів

\begin{tabular}{|l|c|c|}
\hline \multicolumn{1}{|c|}{ Міфоніми } & Кількість & Відсоток вибірки \\
\hline Міфотопоніми & 60 & $29,56 \%$ \\
\hline Міфоантропоніми & 41 & $20,2 \%$ \\
\hline Міфоетноніми & 21 & $10,34 \%$ \\
\hline Міфозооніми & 16 & $7,88 \%$ \\
\hline Міфотеоніми & 14 & $6,9 \%$ \\
\hline Міфотоксиконіми & 14 & $6,9 \%$ \\
\hline Міфохрононіми & 12 & $5,91 \%$ \\
\hline Міфохрематоніми & 9 & $4,43 \%$ \\
\hline Міфогексоніми & 9 & $4,43 \%$ \\
\hline Міфофітоніми & 7 & $3,45 \%$ \\
\hline Всього & $\mathbf{2 0 3}$ & $100 \%$ \\
\hline
\end{tabular}

Як видно із таблиці, найбільш представленими із десяти типів виявилися три групи міфонімів: міфотопоніми, міфоантропоніми та міфоетноніми, які сукупно склали майже дві третини вибірки. Кожен 3 інших типів не перевищував 10\% 3 загальної вибірки. Далі ми детально дослідили тактики перекладу, застосовані для кожного типу.

Основними трьома тактиками перекладу міфонімів стали дослівний переклад, запозичення та еквіваленція. В аналізі тактик перекладу ми детально зупинимося саме на цих трьох тактиках, оскільки інші тактики застосовувалися у перекладі менше 10\% одиниць.

\section{1. Переклад міфотопонімів}

Перед глядачами «Гри престолів» відкривається абсолютно новий, інший світ, і всі території i різні географічні об'єкти, розташовані на них, мають власні найменування. Вони служать для створення достовірності, об'єктивності, реальності зображуваних подій. Ми виокремили 60 міфотопонімів, до яких віднесли назви континентів, морів, річок, заток, гір, островів та півостровів, пустель, назви регіонів, міст та вулиць.

До тактики дослівного перекладу перекладачі вдавалися під час перекладу 53\% міфотопонімів, серед яких - назви усіх морів, заток та майже усіх островів і вулиць. Важливою характеристикою цих міфотопонімів $\epsilon$ те, що вони $\epsilon$ так званими,«промовистими» назвами, тобто в них закладена певна характеристика, внутрішня 
форма. Наприклад, складові частини міфотопоніма Slaver's Вау (Затока Работоргівиів) говорять про те, чим це місто відоме, і, відповідно, матимуть певні очікувані асоціації та конотацію. Такі «промовисті» міфотопоніми перекладалися зі збереженням семантичного значення тих морфем або слів, з яких вони складаються, тобто за допомогою дослівного перекладу. Інші міфотопоніми, для передачі яких перекладач вдався до тактики дослівного перекладу: the Shivering Sea (Тремтяче море), Mother of Mountains (Mamip Гip), the Sapphire Isle (Сапфipoвиŭ Ocmpis), the Iron Islands (Залізні острови), Garden of Bones (Сад Кісток), Shadow Lands (Тінисті Землі), King's Landing (Королівська Гавань), the East Road (Східна дорога) тощо.

Тактикою запозичення було перекладено 37\% міфотопонімів. Не всі міфотопоніми містять в собі явне семантичне наповнення, але вони сприймаються глядачем як показник нереальності та незвичайності світу, який зображується в серіалі. Такі назви географічних об'єктів перекладаються за допомогою тактики запозичення. Цим способом перекладач передав назви майже усіх міст. Наприклад, для передачі міфотопоніма Winterfell, столиці Королівства Півночі та родового замку дому Старків, перекладач вдався до тактики запозичення. У перекладі він звучить як Вінтерфелл, цю лексему було транслітеровано. Знову ж таки, таке перекладацьке рішення зумовлено відсутністю можливості передати значення вихідної одиниці за допомогою дослівного перекладу i зберегти ії коротку форму, тобто передати міфотопонім в максимально наближеній до оригіналу формі. Тактикою запозичення було перекладено i назви континентів Westeros (Becmepoc); річок the Rhoyne (Рӧ̈н); островів the Arbor (Арбор), the Tarth (Tapm); регіонів Lannisport (Ланнісnорm) та інших міст, наприклад, Lorath (Лорат), Braavos (Браавос).

До тактики еквіваленції перекладач вдався під час перекладу 5\% міфотопонімів: регіонів the Reach (Розліг), the Neck (Перешийок) та річки the Trident (Тризубеиь).

До інших тактик перекладач вдався під час перекладу 5\% міфотопонімів. Під час перекладу міфотопоніма the Street of Sisters перекладач вдався до тактики опущення та передав ії на українську як вулищя. Тактику транспозиції було застосовано для передачі міфоніма the Street of Steel (Залізна вулиия). Під час перекладу міфотопоніма the Red Fork (Червоний Зубець) перекладач застосував тактику модуляції.

\section{2. Переклад міфоантропонімів}

Значна частина прикладів припадає на імена героїв, їхні прізвища та прізвиська - це 38 міфоантропонімів. Як правило, під час перекладу імен та прізвищ застосовується тактика запозичення, тобто ім'я або прізвище транскрибується або транслітерується. Однак у літературі в іменах, а особливо в прізвиськах, може бути закладений особливий зміст, який не передається під час застосування тактики запозичення, що призводить до втрати змісту. Тому перекладач застосовує також тактики дослівного перекладу, або еквіваленцію.

Під час перекладу більшості міфоантропонімів перекладач вдався до дослівного перекладу - у $50 \%$ випадків. Розглянемо переклад міфоантропоніма Kingslayer (Царевбивия) - це прізвисько, яке належить Джеймі Ланністеру. У цьому випадку під час перекладу була застосована тактика дослівного перекладу: king [король, цар] + slayer [вбивця]. Ще один приклад - Night King (Король Hoчi) - лідер білих блукачів, наймогутніший та найнебезпечніший серед них. Це істота із чистого льоду і холоду, і тому він має здатність заморожувати все, до чого б він не доторкнувся та куди б не пішов. За допомогою своєї магії може оживляти мертвих (людей, тварин і драконів), щоб ті служили його армії. Король Ночі має здатність перетворювати немовлят в Білих Блукачів (White Walkers), притискаючи палець до щоки дитини. Передача міфоантропоніма відбулася за допомогою тактики дослівного перекладу з перестановкою компонентів: night [ніч] + king [король].

Red Priestess (Червона Жриия) є однією 3 головних героїнь серіалу, яка володіє багатьма вражаючими магічними здібностями. Наприклад, вона мала здатність створювати чари, магічні ілюзії, які змінюють фізичне сприйняття і зовнішній вигляд людей і предметів. Українською цей міфонім передано за допомогою тактики дослівного перекладу: red [червона] + priestess [жриця]. Дослівно також було перекладено і такі міфоантропоніми: High Sparrow (Верховний Горобець), Grey Worm (Сірий Хробак), Young Wolf (Молодий Вовк), Lord of Bones (Лорд Кісток), Protector of the Seven Kingdoms (Захисниия Семи королівств).

Для перекладу комплексних лексем, які складаються 3 власного імені та 3 титулу або прізвиська, застосовувалася комбінація двох тактик - дослівний переклад та запозичення (24\%). Наприклад, у випадку з перекладом міфоантропоніма Tormund the Giantsbane (Тормунд Вбивия Велетнів) перекладач транслітерував ім'я та дослівно переклав прізвисько - giants [велетні] + bane [вбивця]. Ці дві тактики застосовувалися під час перекладу міфоантропонімів Khaleesi of the Great Grass Sea (Кхалісі Великого Зеленого моря), Brandon the Builder (Брандон Будівничий), Baelor the Blessed (Бейлор Благословенний) тощо.

Тактикою еквіваленції було перекладено $18 \%$ міфоантропонімів. У випадку з простими 
прізвиськами перекладач підбирав усталені еквіваленти в українській мові. Міфоантропонім Spider було передано на українську словом Павук. Так прозвали Варіса, Майстра над шептунами, через те, що він, як павук, плете павутину з чуток і змов. Усталені еквіваленти були підібрані і для міфоантропонімів Littlefinger (Мізинеиь), the Mountain (Гора) тощо.

До інших тактик перекладач вдався під час перекладу 8\% міфоантропонімів. Це, зокрема тактика транспозиції при передачі міфоантропонімів Faceless Men (Безликі), Mad king (Безумеиь) тощо.

\section{3. Переклад міфоетнонімів}

Дж. Мартін розробив власний Всесвіт, населив його різними народами і кожному 3 них дав найменування. Ми відібрали 21 міфоетнонім, 8 з яких позначають назви народів, а інші 13 - це назви менших груп людей, племен та кланів.

Під час аналізу тактик перекладу кожного 3 міфоетнонімів було виявлено, що більшість із них було перекладено за допомогою тактики дослівного перекладу (48\%). Застосування тактики дослівного перекладу сприяло збереженню внутрішньої форми назви народу. Наприклад, міфоетнонім First Men перекладено дослівно: first [перші] + men [люди]. Цю ж тактику застосовано під час перекладу міфоетнонімів: Ironborn (Залізнороджені), Free folk (Вільний Народ).

Другою за частотністю застосування є тактика запозичення, і нею було передано $38 \%$ міфоетнонімів. Для полегшення адаптації оніма зазвичай застосовується певна граматична модифікація, у випадку перекладу з англійської на українську це частіше за все додавання родового закінчення або суфікса. Наприклад, назву кочового племені Eccoca the Dothraki було передано на українську за допомогою тактики запозичення - Дотракійці. Перекладач транскрибував цей міфоетнонім та додав до нього закінчення -йці. Отже, структура міфоніма відповідає найпродуктивнішій українській словотвірній моделі назви народу із суфіксом -ець. Перекладач адаптував отриманий у результаті перекладу тактикою запозичення приклад до граматичної структури української мови. Тактикою запозичення було перекладено міфоніми Karstarks (Карстарки), Valyrians (Валірійці), Blackwoods (Блеквуди) тощо.

Варто зазначити, що еквіваленція, одна із трьох основних тактик, не була застосована під час перекладу жодного міфоетноніма. Під час перекладу 14\% міфоетнонімів застосовувалися інші тактики, зокрема: під час перекладу Burned Men (Спалені) та cave people (печерники) застосовано тактику транспозиції, а під час перекладу Stone Crows (Гірські Ворони) - тактику модуляціï.

\section{4. Переклад міфозоонімів}

Свідченням авторської міфотворчості є створені автором істоти, що населяють світ фентезі.
У ході дослідження ми відібрали 16 міфозоонімів, до яких віднесли назви не лише тварин, а й вигаданих автором істот та істот взятих із наявних міфологій.

Більшість із них було перекладено за допомогою тактики еквіваленції - 56\%. У серіалі присутні істоти, які Дж. Мартін запозичив 3 інших міфологій. Відповідно, для передачі цих міфозоонімів українською було використано усталений відповідник. Це істоти зі скандинавської міфології - giants (велетні) та krakens (кракени); грецької - harpy (гарnii); перської - manticore (мантикора). Деякі істоти згадуються у міфологіях різних народів світу - mermaid (русалка), dragon (дракон), cannibals (канібали) та shadow (тінь).

Другою за частотністю застосування є тактика дослівного перекладу, яку застосовано під час перекладу 31\% міфозоонімів. Її використано для перекладу міфозооніма three-eyed raven (триокий ворон). Після того як Бран Старк падає 3 вежі та втрачає змогу ходити, він починає мати видіння цього ворона у своїх снах. Він дає Брану змогу бачити минуле, сьогодення і майбутне та здійснювати подорожі в часі. Дослівно було передано також міфозооніми ice spiders (льодяні павуки) та direwolf (лютововк).

До інших тактик перекладач вдався під час перекладу 13\% міфозоонімів. Це, зокрема, тактика адаптації під час перекладу grumkins and snarks. Це істоти, якими залякують дітей, розповідаючи про них у казках. Вважається, що про них говорять так само, як і про привидів, гоблінів, вампірів та інших страховиськ. Перекладач вирішив адаптувати назви цих істот та передав їх словосполученням бабаї та хохи. Вибір цієї тактики перекладу у даному випадку доцільний, оскільки в українській культурі це відомі персонажі казок, тому це допомагає глядачеві вловити значення цих лексем. Тактика запозичення не застосовувалася під час перекладу міфозоонімів.

\section{5. Переклад міфотеонімів}

Релігія - невід'ємна складова частина авторської міфологічної картини світу «Гри престолів», адже безліч релігійних культів змагалися один 3 одним. Ми виділили 14 міфотеонімів, 50\% 3 яких було передано на українську мову тактикою дослівного перекладу. Так, у Дотракійців присутній культ поклоніння божеству Great Stallion (Великий Жеребеиь), у Лазарян - Great Shepherd (Великий Пастух), у Залізнороджених - Drowned God (Потонулий Бог), у Безликих - Many-faced God (Багатоликий Бог), у людей Ессоса - Lord of Light (Володар Світла), у людей північного Вестеpoca-Old gods (Cmapi боги), на півдні ж найпоширеніша релігія - Faith of Seven (Bipa в Сімох). Для перекладу кожного 3 перелічених міфотеонімів було використано тактику дослівного перекладу, наприклад: great [великий] + shepherd [пастух]. 
Інші 50\% міфотеонімів було передано тактикою еквіваленції, кожен із них передавався за допомогою усталеного еквіваленту слова в українській мові. До прикладу, Віра в Сімох стверджує, що є один Бог, який має сім сонмів: the Father (Oтець), the Mother (Mamip), the Maiden (Діва), the Crone (Стара), the Smith (Коваль), the Warrior (Воїн) i the Strange (Невідомий).

\section{6. Переклад міфотоксикономів}

Окрему групу ми сформували 3 міфонімів, назви яких позначають отруту, адже всі вони вигадані автором, тому представляють інтерес із точки зору аналізу словотвору та їх передачі на українську мову. Таких міфонімів $€ 12$, i, оскільки більшість 3 них має внутрішню форму, 79\% було передано за допомогою тактики дослівного перекладу. Розглянемо переклад отрути Long Farewell (Довге Прощання). Як випливає з назви, для того, щоб ця отрута подіяла, потрібен деякий час, але вона дуже смертоносна. Отрута використовується у вигляді кристалів аметистового кольору, які подрібнюють і розчиняють в напоях для жертви. Однієї краплі, що потрапила на шкіру, досить, щоб заподіяти смерть. Міфонім перекладено дослівно: long [довге] + farewell [прощання]. Дослівно також передано міфоніми widow's blood (вдовина кров), sweetsleep (солодкий сон), dragonglass (драконяче скло).

За допомогою еквіваленції перекладач передав 7\% міфонімів на позначення отрути, це - strangler (душитель). Під час перекладу інших 14\% міфонімів на позначення отрути перекладач застосував інші тактики, зокрема транспозицію при передачі міфоніма shade of the evening (вечірнії тіні). Тактика запозичення не застосовувалася для перекладу міфотоксиконімів.

\section{7. Переклад міфохрононімів}

Міфохрононіми - створені автором власні назви на позначення історичних подій, свят та інших соціокультурних явищ, які є важливими для зображуваного суспільства. Ми виділили 12 міфохрононімів та, проаналізувавши їхній переклад, визначили, що $83 \%$ було передано тактикою дослівного перекладу. Наприклад, The festival of Mother (Фестиваль Mатері) - це релігійне свято, присвячене матері, аспекту семиликого божества Віри в Сімох. Імовірно, його святкують щороку в Королівській Гавані і в усьому королівстві. На українську мову цей міфохрононім передано за допомогою тактики дослівного перекладу: festival [фестиваль] + mother [матір].

За допомогою тактики еквіваленції перекладено 8,5\% міфохрононімів. The Doom (Загибель) була катастрофічною подією, що сталася майже за чотириста років до війни П'яти королів. За один день столицю Валірійського Фрігольда було зруйновано, і більша частина півострова Валірії спустошено.
Ще 8,5\% міфохрононімів передані іншими тактиками, це, зокрема, тактика модуляції при передачі міфохрононіма the Hand's Tournament (Турнір на честь руки Короля). Тактика запозичення не застосовувалася для передачі жодного міфохрононіма $(0 \%)$.

\section{8. Переклад міфохрематонімів}

До міфохрематонімів ми віднесли 9 одиниць, для перекладу значної кількості яких було застосовано тактику дослівного перекладу - 45\%. Усі міфохрематоніми - це назви мечів, адже вони багато можуть сказати про долі або характер своїх власників. Наприклад, під час свого весілля Джоффрі Баратеон отримує у подарунок меч i просить інших гостей придумати для нього назву. Після кількох варіантів він швидко зупиняється на назві Widow's Wail (Вдовиний Плач), яка підходить жорстокому Джоффрі. Він зауважує, що кожен раз, коли він буде використовувати цей меч, це буде схоже на обезголовлення Неда Старка. Цю назву було перекладено дослівно: widow's [вдовиний] + wail [тужіння, ридання]. Оскільки перекладач намагався зберегти коротку форму назви, він замінив слово «ридання» на «плач». Дослівний переклад $\epsilon$ найбільш вдалим способом передачі подібних міфохрематонімів на українську мову i, на наш погляд, в кожному випадку перекладачеві вдалося передати значення, закладене в оригіналі. Дослівно було передано і такі міфохрематоніми: Longclaw (Довгий Kizomь), Heartsbane (Загибель Сердець) тощо.

Тактику еквіваленції перекладач застосував під час перекладу 33\% міфохрематонімів. Наприклад, Needle (Голка) - назва короткого меча Apiї Старк. Дівчина вирішує дати йому таку назву як глузливе нагадування про шиття, яке вона ненавидить: «Sansa can keep her sewing needles. I've got a needle of my own - Хай Санса бере голки собi. Я тепер маю свою». За допомогою цього міфохрематоніма автор підкреслює особливості характеру героїні.

Іншими тактиками перекладач передав 22\% міфохрематонімів. При передачі назви меча Oathkeeper (Вірний Клятві) була використана тактика транспозиції, а для Terminus (Смертельний Дотик) - тактика модуляції. Тактика запозичення не використовувалася для передачі міфохрематонімів.

\section{9. Переклад міфогексонімів}

Невід'ємним джерелом та одним 3 основних елементів міфологічної картини світу $є$ наявність магії в серіалі. Ми відібрали 12 міфонімів, які позначають види та практики магії у «Грі престолів» та найменування людей та істот, які володіють магічними здібностями.

Тактикою еквіваленції було передано 56\% міфонімів на позначення магії. Для передачі трьох 
міфогексонімів перекладач використав усталені відповідники в українській мові, це - black magic (чорна магія), blood magic (магія крові) та prophecy (пророитво).

Для передачі 22\% міфонімів на позначення магії перекладач вдався до дослівного перекладу, наприклад: dark magic (темна магія). До інших тактик перекладач вдається під час перекладу $22 \%$ міфогексонімів. Зокрема, це тактика модуляціï, до якої перекладач вдався під час перекладу міфоніма warg. Варто зазначити, що слово «warg» існувало ще до «Гри престолів». Назва походить зі скандинавської міфології, і варги згадуються в художній літературі, зокрема у творах Дж. Толкіна, де варги - це гігантські розумні вовки, їздові тварини орків. У світі «Гри престолів» warg - це людина, яка володіє здатністю проникати в свідомість тварин і сприймати світ через їхні органи чуття і навіть керувати їхніми діями. Перекладач передав на українську міфонім warg словом перевертень, вивівши значення міфоніма в українській мові логічно. Застосовано тактику модуляції, оскільки «warg» - це різновид перевертнів, але ці перевертні не перетворюються фізично, а тимчасово переселяють свій розум в тварин. При передачі міфоніма blood spells (чари на крові) перекладач застосував тактику транспозиції. Тактикою запозичення не було перекладено жодного міфоніма на позначення магії (0\%).

\section{0. Переклад міфофітонімів}

Світ «Гри престолів» унікальний не тільки наявністю у ньому міфічних істот, власної географії, а ще й наявністю рослин, референтів яким не існує в реальності. На позначення цих рослин ми відібрали 7 міфофітонімів, 83\% 3 яких були передані на українську за допомогою тактики дослівного перекладу. Розглянемо приклад передачі міфофітоніма ghost grass (примарні трави). Джора Мормонт розповідає Дейнеріс: "In the Shadow Lands beyond Asshai, they say there are fields of ghost grass with stalks as pale as milk that glow in the night. It murders all other grass - У Країні Тіней за Ашаєм, кажуть, ростуть примарні трави з білими, як молоко, стеблами, щзо світяться і нищать інші трави». Цей приклад відображає уявлення Дотракійців про світ. До того ж, опис цієї містичної трави може сприйматися як метафора на білих блукачів. Українською цей міфофітонім передано дослівно: ghost [примара] + grass [трава]. При цьому іменник «примара» замінили прикметником «примарний», оскільки в оригіналі слово «ghost» витупає у функції атрибута. Дослівно було перекладено також winter rose (зимова троянда) і lady's lace (жіноче мереживо).

Один міфофітонім (17\%) перекладач передає тактикою модуляції: heart tree (дерево роду). Тактики запозичення та еквіваленції не застосовувалися для перекладу міфофітонімів.

Загальну інформацію про тактики перекладу, застосовані при відтворенні кожного типу міфонімів, подано у таблиці 2, у якій наведені всі типи міфонімів у порядку спадання їх кількості у вибірці. Дані наводяться у відсотковому співвідношенні, а в дужках подається абсолютна кількість випадків застосування певної тактики. Детальну інформацію наведено лише для трьох основних тактик, тоді як інші, які сукупно застосовувалися в менше, ніж 10\%, віднесено до категорії «інші тактики».

Проведене дослідження дозволяє зробити такі висновки про використання тактик перекладу для відтворення лексичних одиниць, які у оригінальному творі використовувалися для вербалізації авторської міфологічної картини світу:

1) для кожного типу міфонімів застосовувалися різні тактики перекладу, жоден тип не перекладався із застосуванням лише однієї тактики;

2) основною тактикою є дослівний переклад, який був домінантною тактикою (понад 50\%)

Таблиця 2

Тактики перекладу міфонімів

\begin{tabular}{|l|c|c|c|c|c|}
\hline & $\begin{array}{c}\text { Дослівний } \\
\text { переклад }\end{array}$ & Запозичення & Еквіваленція & $\begin{array}{c}\text { Інші } \\
\text { тактики }\end{array}$ & Всього \\
\hline Міфотопоніми & $53 \%(32)$ & $37 \%(22)$ & $5 \%(3)$ & $5 \%(3)$ & $100 \%(60)$ \\
\hline Міфоантропоніми & $51 \%(21)$ & $22(9)^{1}$ & $17 \%(7)$ & $10 \%(4)$ & $100 \%(41)$ \\
\hline Міфоетноніми & $48 \%(10)$ & $38 \%(8)$ & $0 \%$ & $14 \%(3)$ & $100 \%(21)$ \\
\hline Міфозооніми & $31 \%(5)$ & $0 \%$ & $56 \%(9)$ & $13 \%(2)$ & $100 \%(16)$ \\
\hline Міфотеоніми & $50 \%(7)$ & $0 \%$ & $50 \%(7)$ & $0 \%$ & $100 \%(14)$ \\
\hline Міфотоксиконіми & $79 \%(11)$ & $0 \%$ & $7 \%(1)$ & $14 \%(2)$ & $100 \%(14)$ \\
\hline Міфохрононіми & $83 \%(10)$ & $0 \%$ & $8,5 \%(1)$ & $8,5 \%(1)$ & $100 \%(12)$ \\
\hline Міфохрематоніми & $45 \%(4)$ & $0 \%$ & $33 \%(3)$ & $22 \%(2)$ & $100 \%(9)$ \\
\hline Міфогексоніми & $22 \%(2)$ & $0 \%$ & $56 \%(5)$ & $22 \%(2)$ & $100 \%(9)$ \\
\hline Міфофітоніми & $86 \%(6)$ & $0 \%$ & $0 \%$ & $14 \%(1)$ & $100 \%(7)$ \\
\hline Всього & $\mathbf{5 3 , 2 \% ( 1 0 8 )}$ & $\mathbf{1 9 , 2 \% ( 3 9 )}$ & $\mathbf{1 7 , 7 \% ( 3 6 )}$ & $\mathbf{9 , 9 \% ( 2 0 )}$ & $100 \%(203)$ \\
\hline
\end{tabular}

\footnotetext{
'Ці міфоніми ми віднесли до тактики запозичення, хоча вони перекладалися комбінацією тактик запозичення + дослівний переклад
} 
у 6310 типів міфонімів, та значною у 4 iз 10 . Застосування цієї тактики зумовлене тим, що міфоніми оригіналу часто мають «промовисті імена», і перекладачі намагалися зберегти їх значення у цільовій мові;

3) тактика запозичення, незважаючи на те, що виявилася другою за частотністю, застосовувалася лише у 3 типах міфонімів;

4) тактика еквіваленції, натомість, застосовувалася у 8 з 10 типів, хоча сумарно ії частотність поступалася тактиці запозичення. Разом із тим у трьох типах міфонімів еквіваленція виявилася основною тактикою (понад 50\%), до якої вдавалися перекладачі;

5) незважаючи на жанрові особливості тексту оригіналу, у 80\% випадків перекладу міфонімів перекладачі намагаються використати лексичні ресурси цільової мови, коли міфоніми передаються за допомогою дослівного перекладу, або ж за допомогою пошуку еквівалента в цільовій мові. Разом із тим у 20\% міфоніми передавалися через запозичення в українську мову задля збереження екзотичного характеру міфологічної картини світу, створеної автором. Домінантне вживання дослівного перекладу (понад 50\%) свідчить про намір автора зберегти значення оригінальної одиниці, оскільки вона є важливою для контексту оригіналу, є промовистою назвою, а також виконує функцію характеризації елементів міфологічної картини світу автора.

Перспективами подальших розвідок вважаємо дослідження лінгвокогнітивних особливостей перекладу авторської міфологічної картини світу у творчості Дж. Мартіна, а також дослідження тактик перекладу в серії книг «Пісня льоду й полум'я», на якій базується кіносеріал, та порівняння використаних тактик із тими, які застосовувалися у перекладі фільму.

\section{ЛІТЕРАТУРА}

1. Борисова О.В., Юта М.О. Деякі особливості перекладу власних назв на матеріалі роману Дж. Мартіна «Гра престолів» та його перекладу українською мовою. Мовні і концептуальні картини світу. Київ, 2014. Вип. 50, ч. 1. С. 80-85.

2. Великорода Ю.М., Клюка В.В. Переклад авторських неологізмів у кінематографі (на матеріалі кінофільму «Великий дружній велетень») Науковий вісник Херсонського державного університету. Серія Перекладознавство та міжкультурна комунікація. № 3. Херсон, 2018. С. 90-95.

3. Винтерле И.Д. Миф как основа литературы фэнтези Вестник Ниже-городского университета им. Лобачевского. 2012. № 1(2). С. 37-39.

4. Данилова В.С., Кожевников Н.Н. Картины мира и методы их исследования. Вестник ЯГУ, 2007. T. 4. № 3. C. 77-82.

5. Лазарев, М.А. Мифологическая картина мира. Humanity space International almanac. Vol. 6. 2017, № 2. С. 269-282.

6. Моісєєва Н.О. Особливості перекладу неологізмів у текстах німецькомовного політичного дискурсу. Наукові записки [Ніжинського державного університету ім. Миколи Гоголя]. Сер. : Філологічні науки, 2014. Кн. 3. С. 114-118.

7. Невский Б. Жанры. Мифологическая фантастика. Мир фантастики - январь 2007. № 41.

8. Підлужна І.А., Сергієнко М.С. Переклад оказіоналізмів у стилістично маркованих контекстах німецького медіапубліцистичного дискурсу. Науковий вісник Херсонського державного університету. Серія Лінгвістика. № 37. Херсон, 2019. С. 52-57. DOI: https://doi.org/10.32999/ ksu2413-3337/2019-37-10.

9. Присяжнюк І.С., Котковець А.Л. Переклад неологізмів в межах концептуальних сфер «Масова культура», «Література, мистецтво та спорт» Наукові записки. Вип. 144, Серія: Філологічні науки. Кіровоград : Видавець Лисенко В.Ф., 2016. С. 267-270.

10. Подольская Н.В. Словарь русской ономастической терминологии. Изд. 2-е, перераб. и доп. Москва : Наука, 1988. 192 с.

11. Суперанская А.В. Общая теория имени собственного. Москва : Наука, 1973. 366 с.

12. Newmark, P. (1988). A Textbook of Translation. New York : Prentice Hall.

13. Vinay, J-P., Darbelnet, J. (1995). Comparative Stylistics of French and English: a Methodology for Translation. Trans. of Vinay - Darbelnet (1958) by Sager, J. C. \& Hamel, M-J. Amsterdam/Philadelphia: John Benjamins.

\section{REFERENCES}

1. Borysova O.V., Yuta M.O. (2014). Deyaki osoblyvosti perekladu vlasnykh nazv na materiali romanu Dzh. Martina "Hra prestoliv" ta yoho perekladu ukrayinskoyu movoyu [Some characteristics of the translation of proper names on the basis of the translation of G. Martin's novel "Game of Thrones"]. Lingual and conceptual worldviews. Vol. 50, p.1 P. 80-85. 
2. Velykoroda Y.M., Klyuka V.V. (2018) Pereklad avtorskykh neolohizmiv u kinematohrafi (na materiali kinofilmu «Velykyy druzhniy veleten») [Translation of author's neologisms in cinematography (on the bases of the film "The BFG”)]. Journal of Kherson state university. № 3. P. 90-95.

3. Vynterle Y.D. (2012) Mif kak osnova literatury fentezi [Myth as the basis for fantasy]. Nizhni Novgorod university journal № 1 (2). P. 37-39

4. Daniova V. S., Kozhevnikov N.N. (2007) Kartiny mira i metody ikh issledovanyya [Worldviews and methods of their research]. YAHU Journal. Vol. 4. № 3. P. 77-82.

5. Lazarev, M. A. (2017). Mifologicheskaya kartina mira [Mythological worldview]. Humanity space International almanac. Vol. 6. 2017, P. 269-282.

6. Moisyeyeva N. O. (2014) Osoblyvosti perekladu neolohizmiv u tekstakh nimetskomovnoho politychnoho dyskursu [Translation of neologisms un German political discourse texts]. Proceedings of Nizhyn state university. Series: Philology, Book 3. P. 114-118.

7. Nevskiy B. (2007) Zhanry. Mifologicheskaya fantastika [Genres. Mythological fiction] World of fiction. January 2007. № 41.

8. Pidluzhna I.A., Serhiyenko M.S. (2019). Pereklad okazionalizmiv u stylistychno markovanykh kontekstakh nimetskoho media-publitsystychnoho dyskursu [Translation of occasionalisms inn stylistically marked contexts of German media discourse] Journal of Kherson state university. Series linguistics. № 37. P. 52-57. DOI: https://doi.org/10.32999/ksu2413-3337/2019-37-10

9. Prysyazhnyuk I.S., Kotkovets A.L. (2016) Pereklad neolohizmiv v mezhakh kontseptualnykh sfer "Masova kultura", "Literatura, mystetstvo ta sport" [Translation of neologisms in conceptual spheres "Mass culture", "Literature, art and sport"] Proceedings. Vol. 144, Series: Philology. P. 267-270.

10. Podolskaya N. V. (1988) Slovar russkoy onomastycheskoy termynologii [Dictionary of Russian onomastic terminology]. Second edition. $192 \mathrm{p}$.

11. Superanskaya A.B. (1973). Obshchaya teoriya imeny sobstvennogo [General theory of proper name]. $366 \mathrm{p}$.

12. Newmark, P. (1988). A Textbook of Translation. New York : Prentice Hall.

13. Vinay, J-P., Darbelnet, J. (1995). Comparative Stylistics of French and English: a Methodology for Translation. Trans. of Vinay - Darbelnet (1958) by Sager, J. C. \& Hamel, M-J. Amsterdam/Philadelphia : John Benjamins. 